\title{
Investment Management of Agro-Ecological Farms
}

\author{
Victoria Borisova, ${ }^{1, *}$, Iryna Samoshkina ${ }^{1}$ \\ ${ }^{1}$ Sumy National Agrarian University, Department of Finance, Sumy National Agrarian University, G. Kondratyeva Str., bld. 160 \\ Sumy, 40021, Ukraine
}

\begin{abstract}
The effective development of farms requires the environmental and economic investing, which provides for investments in improving the soil quality that can be enhanced through a fresh look at the problem of degradation, given that agricultural land is considered to be produced, not primary resource, similar to all other kinds of resources accounted in agriculture. The degradation and restoration of land productivity are the problems of the analysis of investment updates, modified with the aim of establishing the relationship of the soil quality and relevant investments. The effective investing of additional capital is crucial for the successful investment activities of agro-ecological farms, while investment resources are subject to management. The stirring up of investment activities is possible on the basis of the environmental and economic planning of farms as the important link in the structure of the organizational and economic mechanism of farm operation, the efficient investment management. The article focuses on the directions of attracting investments in agro-ecological farms and agricultural enterprises to improve their business performance. The investment attractiveness of environmental agribusiness is justified. The features of management and trends in the development of the investment activities of agro-ecological farms are identified.
\end{abstract}

\section{Introduction}

Agroecology is the study of ecological processes applied to the design, development, and management of agriculture. Agro-ecological is a specialist asset manager focused on farmland as an asset class managed ecologically.

Management of all aspects of the investment activity of enterprise occupies the central place in the organizational and economic mechanism of intensification of the investment process in agribusiness. It includes management of investment projects, economic and financial levers.

During the period of 1991-2016 in Ukraine crop acreage decreased by $16.8 \%$; forage acreage decreased by 4.6 times, that negatively affected the development of fodder supply of the livestock industry. During that period planting of lucrative export-oriented crops significantly increased: sunflower by 2.8 times, rape by more than 10 times that violates the crop rotation system and results in soil depletion. Acreage under potatoes and vegetables and melon crops has decreased by $5.0 \%$, now these crops are concentrated mainly in households [1].

Motivation to attract investment in agro-ecological production depends on financial stability, flexibility and stimulating character of the tax policy, completion of the reform of ownership. Creation of favorable investment climate in the agrarian sector and promotion of investment activity of all economic entities, considering the current financial and material-technical provision of agricultural enterprises and agro-ecological farms need solution of the issue of quality changes in approaches to the management of agro-industrial production as a whole, every industry and business entity. Therefore, it is essential to form an effective mechanism of the ecological and economic investment management in the agrarian sector, adequate to the conditions of current economic status, taking into account the specifics of agricultural production, that will be able to create profitable conditions for stimulating savings of agricultural capital, and increasing the efficiency of its use, that is possible due to the development of ecological agribusiness.

\section{Research goals, tasks, objects and methods}

Goal of the research is to draw up scientifically grounded proposals for the development of ecological and economic investments of agricultural enterprises and agro-ecological farms, promotion of investments in the agribusiness to increase its economic efficiency and to expand the production of environmentally friendly farm products. Implementation of this goal is associated with the solution to the following tasks:

- to study the features and trends of investment in the economy of Ukraine;

- to justify the essence of investment attractiveness of agro-ecological entrepreneurship; make classification of organizational, economic and ecological measures of agricultural land protection; 
- to analyze the features of investment management of agro-ecological farms.

Object of the research is ecological and economic investments of agricultural enterprises and agroecological farms in Ukraine, practice of its implementation as a tool of investment management.

The following methods were used in the research: abstract-logical (to clarify the conceptual provisions of the development of investment management of agroecological farms, to make the economic assessment of the agricultural technologies of deficit-free humus balance), analytical (to justify the information-analytical support for the process of management of attracting investments in agro-ecological farms), statistical (to analyze capital investments in Ukraine by types of economic activities, investment activities of agroecological farms; to make the calculation and economic assessment of the agricultural technologies of deficit-free humus balance in growing winter wheat), normative (to justify the value of humus depending on the cost of raw materials for its formation), etc.

\section{Environmental and economic investment agro-ecological farms}

\subsection{Features of attracting investments in the economy of Ukraine}

The experience of the advanced economies shows that the agribusiness sector is attractive for investments, as there is always a steady demand for agrarian production, which has no tendency towards reduction, and the agricultural products (in contrast to their production technologies) get never out of date "technically and technologically", that is confirmed by the evolutionary process of economic development.

In Ukraine in 2016 economic entities from all sources of financing in agriculture, forestry, fishery invested 1.95 billion USD in fixed capital, that is $49.65 \%$ more than in 2015. The share of investment in these economic activities is $14.05 \%$ of the national volume of investments in fixed capital (in 2015 - 11.04\%) [2]. Capital investments by types of economic activity are given in Table 1.

Table 1. Capital investments by types of economic activity for 2014-2016 (million USD)*.

\begin{tabular}{|l|c|c|c|}
\hline \multicolumn{1}{|c|}{ Economic branch } & $\mathbf{2 0 1 4}$ & $\mathbf{2 0 1 5}$ & $\mathbf{2 0 1 6}$ \\
\hline Total & 14,667 & 11,798 & 13,875 \\
\hline $\begin{array}{l}\text { Agriculture, forestry and } \\
\text { fisheries, including: }\end{array}$ & 1,256 & 1,303 & 1,950 \\
\hline $\begin{array}{l}\boldsymbol{\bullet} \text { agriculture, hunting } \\
\text { and provision of the } \\
\text { related services }\end{array}$ & 1,229 & 1,266 & 1,918 \\
\hline $\begin{array}{l}\text { - forestry and timber } \\
\text { logging }\end{array}$ & 25 & 34 & 30 \\
\hline $\boldsymbol{\bullet}$ fisheries & 2 & 2 & 2 \\
\hline
\end{tabular}

\begin{tabular}{|c|c|c|c|}
\hline Economic branch & $\mathbf{2 0 1 4}$ & $\mathbf{2 0 1 5}$ & $\mathbf{2 0 1 6}$ \\
\hline Industry & 5,765 & 3,786 & 4,548 \\
\hline Construction & 2,410 & 1,878 & 1,717 \\
\hline Other services & 3,980 & 3,529 & 3,710 \\
\hline Total (\%) & 100.00 & 100.00 & 100.00 \\
\hline $\begin{array}{l}\text { Agriculture, forestry and } \\
\text { fisheries (\%), including: }\end{array}$ & 8.56 & 11.04 & 14.05 \\
\hline $\begin{array}{l}\text { - agriculture, hunting } \\
\text { and provision of the } \\
\text { related services (\%) }\end{array}$ & 8.38 & 10.73 & 13.82 \\
\hline $\begin{array}{l}\text { - forestry and timber } \\
\text { logging (\%) }\end{array}$ & 0.17 & 0.29 & 0.22 \\
\hline$\bullet$ fisheries (\%) & 0.01 & 0.02 & 0.01 \\
\hline Industry (\%) & 39.31 & 32.09 & 32.78 \\
\hline Construction (\%) & 16.43 & 15.92 & 12.37 \\
\hline Other services (\%) & 27.14 & 29.91 & 26.75 \\
\hline
\end{tabular}

* Calculated by the author according to the Office for National Statistics of Ukraine, excluding the temporarily occupied territory of the Autonomous Republic of Crimea and Sevastopol; without part of the antiterrorism operation zone [2]

The capital investments in the amount of 0.42 billion USD, accounting for $16.8 \%$ of their total volume in Ukraine [2, 3], were made in the development of the enterprises of agriculture, forestry and fisheries during January-March 2017. The most important direction of investments in the reproduction of natural resources used in the agrarian sector is the financing of measures aimed at improving soil fertility, as soil is irreplaceable and geographically limited means of production.

The unsatisfactory ecological state of Ukrainian farmland, primarily black soil, is of particular concern. 11 million tons of humus, 0.4 million tons of phosphorus and 7 million tons of potassium are annually taken out of soil that is 2.3 times more than the quantity thereof put in with fertilizers [4]. Over the past decade, the process of soil dehumification has accelerated. The trend towards the soil quality deterioration during the production of monocultures has been detected even before the mechanization and chemicalization which have triggered it by affecting adversely the soil bioproductivity through the compaction, accumulation of pesticides and other harmful substances. The irrational use of mineral fertilizers and chemical means of plant protection leads to an increase in the scale of soil contamination, threatens human health, endangers the stability of ecosystems $[5,6]$.

The goal of the eco-economic planning of agricultural production is not only the determination of the conditions necessary to increase production, but also ensuring a balance between the production and environment, where land plays a major role. In the agricultural natural resource management an increased focus should be put on the environmental aspects of land 
use such as the protection of land resources from contamination and the restoration of degraded lands, with the aim of their further effective use by current and future generations, that requires attracting investments.

\subsection{Investment attractiveness of agro-ecological entrepreneurship}

The strengthening of government control over land use and environmental conditions leads to the development of environmental entrepreneurship - specific form of socially useful activities, the essence of which lies in the reproduction and rational use of natural resources involved in the production. The economic expediency of agro-ecological entrepreneurship is obvious: first and foremost, it is the return of free goods, 'lost' for the society, to agricultural resource circulation, attraction of previously inaccessible resources.

Considering the world experience in economic solutions to environmental problems of agriculture, the impetus for the development of agro-ecological entrepreneurship in Ukraine should be tax incentives for environmental investment - investment in ecologically sound technologies and equipment through tax methods [5, 7].

Evaluation of economic efficiency of investment plays an important role in determining the investment attractiveness of agro-ecological farms. An integrated assessment of social, ecological and economic results of investment activities in agricultural production can be developed, provided that social and environmental outcomes expressed in physical indicators, can be denominated in value terms. However, the specific features of agricultural production complicate social, environmental and economic evaluation of the effectiveness of investment in agriculture. The most important ones include the uneven machinery use over time, structural changes in soil (water-air regime, erosion resistance, microflora and zoofauny development), the impact of a number of biological factors, especially the chemical composition of the air in livestock houses, accompanied by a high content of pollutants (ammonia, hydrogen sulphide, carbon dioxide and others). Social outcomes in agricultural production are sometimes manifested not immediately, but after a lag. In addition, they are formed indirectly through flora and fauna. Environment is the first to be affected: air, soil, water, which in turn in modified form influence the flora and fauna, and the last have impact on a person through food consumption.

A crucial prerequisite for successful investment activity of enterprises in market conditions is the efficient investment of additional capital, as investments are subject to control. Therefore, the intensification of investment activity in the agribusiness on the micro and macro levels should be controlled. Enhancement of investment is possible on the basis of planning, which is an important element in the structure of the organizational and economic mechanism. In order to attract investment it is necessary to develop an investment project or program. Potential investor assesses production process in terms of environmental protection and conservation measures which should ensure compliance with the project:

- reduction in emissions that meet environmental standards in Ukraine;

- lack of toxic and hazardous substances;

- maintenance and improvement of land quality;

- rational use and decline in the amount of natural resources involved in the exploitation;

- decrease in emissions of pollutants into the environment.

The high development of the state soil reserves in Ukraine $(70.9 \%$, the level of tilled soil is $53.8 \%$, including $77.9 \%$ of farmland) and extensive use of productive land result in the increased land degradation, soil loses its fertility and becomes depleted. According to the Ministry of Agrarian Policy and Food of Ukraine 13.2 million hectares of agricultural land suffer from water erosion, 19.3 million hectares from wind erosion, another 10.7 million hectares degrade due to high acidity, 3.9 million hectares are saline lands, 3.6 million hectares are wetlands. The area of arable land that has been degrading due to erosion for the last 25 years has increased by one-third. And every year this degradation is expanding at 90-100 ha, and humus content in soil reduces by $20 \%$ [4]. Cuts in financing of erosion preventive measures result in reduction in land protection measures. Therefore, trends of increasing efficiency of agricultural land use should be as follows:

- improvement in quality of soil surface (maintenance of physical and mechanical soil conditions, water regulation), which undergoes changes as a result of improper agricultural use;

- prevention of erosion processes with simultaneous improvement in land fertility (reducing the intensity of mechanical treatment of soil with heavy machinery, reducing the number of passes across the field);

- implementation of reclamation measures on acid soils and salt water marshes, increasing humus in soils by proper usage of organic and mineral fertilizers;

- prevention from soil contamination by technogenic factors and agricultural use;

- introduction of science-based systems of crop rotation by various entities in the agricultural sector;

- improvement in the structure of crop acreage.

Protection of agricultural land is based on a combination of organizational, economic and environmental elements of influence on businesses in order to comply with the requirements of the rational use and protection of land as the most essential element of the economic system, universal means of production and unique natural resource (Figure 1).

Under conditions of transformation of agricultural relations the role of organizational and economic mechanism of the efficient agricultural land use such as: financing, pricing, lending, taxation and insurance coverage increases dramatically in the presence of sound organizational and administrative and legal support [3]. Sources of financing the systems of measures aimed at land use and protection should be formed at the expense of state and regional budgets, administrative areas and farms, special off-budget state and other funds [8]. 
It is expedient to create a flexible system of incentives for improving the ecological condition of land by establishing tax and other benefits granted to the enterprises, companies, institutions and citizens while ensuring the quality of land that meets the environmentally sound standards, to release the enterprises from taxation of profit obtained from the investments allocated for the construction of soil and environmental protection facilities, introduce a system of benefits for producers of environmentally friendly products [9].

Land use in Ukraine is paid and land rental is in the form of land tax or rent for landowners and land users. These funds should be used exclusively to finance the management of soil fertility. Moreover, additional sources of stimulation for improving the efficiency of land use may be payments to the budget when removing unproductive lands from agricultural turnover and funds from the payment of penalties.

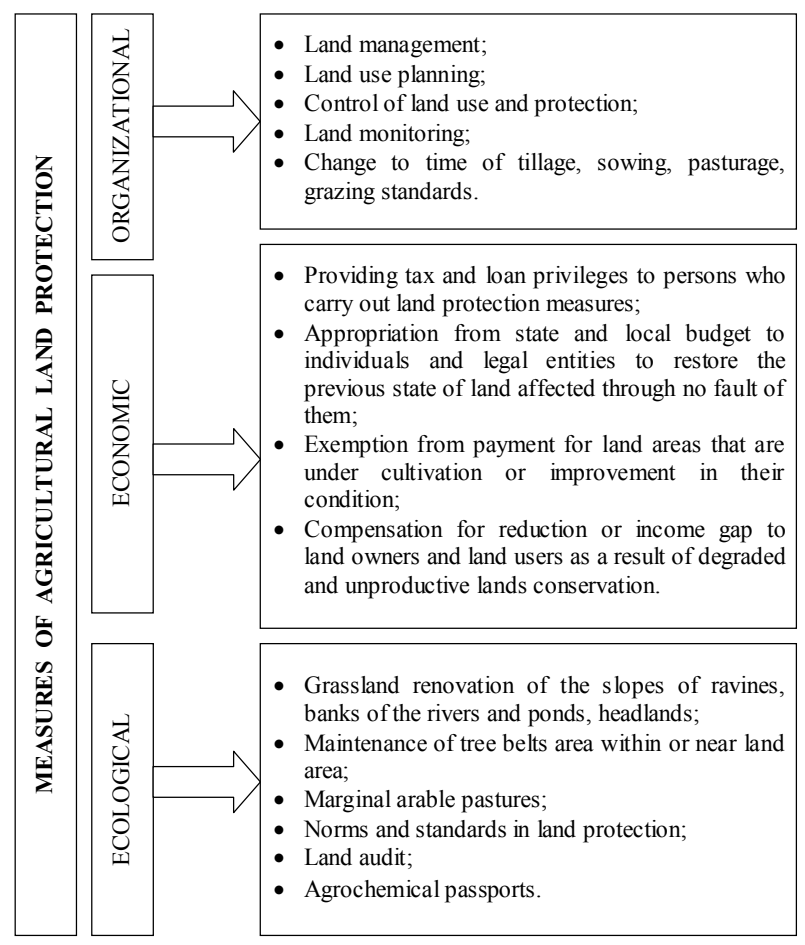

Fig. 1. System of Organizational, Economic and Ecological Measures of Agricultural Land Protection,

Source: Authors' presentation

Economic incentive for improving agricultural and ecological status of agricultural land is based on the methods of monetary valuation of land. Motive of economic incentives for landowners and land users is to increase agricultural and ecological score of land, which is determined at regular agrochemical examination. A necessary condition for stimulating is a growth of agrochemical indicators of soil fertility $[10,11]$.

Economic lever of influence on the land use efficiency is ecological and agrochemical score of land. Penalties should be applied for deterioration of ecological conditions of land. In the event that agricultural and ecological score of soils did not change during the latest agrochemical examination, it would be inexpedient to conduct stimulation. Economic incentives should not exceed the penalties when agricultural and ecological score tends upwards or downwards. It will promote the economic interests of landowners and land users in increasing land fertility, increase the value of agricultural and ecological score.

Therefore the main ecological and economic principles of rational use, restoration and protection of productive land, including eroded soils are: the advantage of long-term social and economic programs and approaches over the short-term needs; the complexity of solving environmental problems and issues of fertility restoration and preservation of eroded land, rational use of land resource potential, integration, interrelation of natural resources and logistical components of the total resource potential of agricultural production.

\section{Investments in soil fertility recovery}

Investments in the soil improvement expand the range of the capabilities of agricultural enterprises and farms, taking into consideration the location of products and resources. In addition to choosing technologies and crops, the optimization problem involves the allocation of resources between different types of products and future land quality [12]. Earlier on, the models used to represent the special cases, when agricultural enterprises were believed to be able to deplete the soil, though to different extents, depending on the productive and technological choices. The empirical significance of this "approach" to the soil degradation becomes apparent, and the need for their ecological and economic development is considered as well.

The problem of the soil fertility management is quite complicated and poorly studied, but it is the most rational way to produce cheap and ecologically pure products without outward investments under modern conditions in Ukraine. The study has shown the possibility of replacing missing or insufficient quantities of organic fertilizers of animal origin in a vegetable way $[13,14]$ : the replenishment of humus in the soil through the use of grain crop straw and other by-products; changes in the structure of sowing areas to increase the acreage of perennial grasses; the cultivation of green manure.

Our study has shown that about $1-1.5$ million tons of straw stored in stacks and remaining unused are annually accumulated under the conditions of Sumy region (Ukraine). The wasted labor and means of production for growing and stacking straw turn to be useless, but, by the way, they are significant. Thus, if the estimated cost of $1 \mathrm{t}$ of straw is $1.16 \mathrm{USD}$, such costs will be from 1.16 to 1.74 million USD as a whole in Sumy region. On the other hand, all the prepared straw in the accounting registers of farms is recorded as the straw used for the production needs, i.e. the actual cost of agricultural production is overestimated.

We believe that it is essential to store the optimal, economically justified amount of straw for the 
production purposes, and the rest of it should not be burnt, but used to replenish soil with organic matter. The evaluation of costs per unit of humus is made depending on the used vegetable or animal organic fertilizers (Table 2).

Table 2. Calculated data for the formation of humus and its cost under the conditions of Sumy region (Ukraine),

\begin{tabular}{|c|c|c|c|c|}
\hline $\begin{array}{c}\text { Types of } \\
\text { organic } \\
\text { fertilizers }\end{array}$ & $\begin{array}{c}\text { Cost of 1t } \\
\text { of organic } \\
\text { fertilizers } \\
\text { USD }\end{array}$ & $\begin{array}{c}\text { Coefficient of } \\
\text { humification }\end{array}$ & $\begin{array}{c}\text { Amount of } \\
\text { humus formed, } \\
\text { c }\end{array}$ & $\begin{array}{c}\text { Cost of 1c of } \\
\text { humus, USD }\end{array}$ \\
\hline $\begin{array}{c}\text { Green } \\
\text { manure }\end{array}$ & 0.52 & 0.15 & 1.5 & 0.35 \\
\hline $\begin{array}{c}\text { Litter } \\
\text { manure* }\end{array}$ & 1.55 & 0.10 & 1.0 & 1.55 \\
\hline $\begin{array}{c}\text { Peat } \\
\text { festering } \\
\text { compost }\end{array}$ & 1.55 & 0.15 & 1.5 & 1.03 \\
\hline Straw & 1.16 & 0.11 & 1.1 & 1.07 \\
\hline $\begin{array}{c}\text { On } \\
\text { average }\end{array}$ & - & - & - & 1.00 \\
\hline
\end{tabular}

* Adjusted for the cost of work on transportation and fertilizer application

Source: Authors' presentation

The above calculations have shown that the humus formed from vegetable organic fertilizers is cheaper than the humus formed from manure. The determination of the evaluation of $1 \mathrm{c}$ of humus enables to make a comparative assessment of the economic feasibility of certain options for enhancing fertility, depending on the farm specialization. The results of these calculations are given in Table 3 .

Table 3. Cost of humus depending on cost of raw materials for its formation.

\begin{tabular}{|c|c|c|c|c|c|}
\hline \multirow[b]{2}{*}{$\begin{array}{l}\text { Features of } \\
\text { options }\end{array}$} & \multicolumn{2}{|c|}{$\begin{array}{c}\text { Humus } \\
\text { formed, } \\
\text { kg/ha }\end{array}$} & \multicolumn{2}{|c|}{$\begin{array}{l}{ }^{*} \text { Cost of } \\
\text { humus, } \\
\text { USD/ha }\end{array}$} & \multirow{2}{*}{ 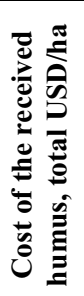 } \\
\hline & 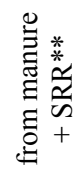 & 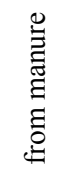 & 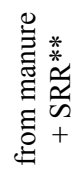 & 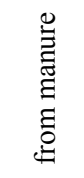 & \\
\hline \multicolumn{6}{|c|}{ Forest-Steppe Zone } \\
\hline $\begin{array}{c}\text { Grain } \\
\text { specialization, } 0.3 \\
\text { head of cattle per } 1 \\
\text { ha }\end{array}$ & 1071 & 250 & 11.41 & 3.88 & 15.29 \\
\hline $\begin{array}{c}\text { Grain-dairy- } \\
\text { vegetable, } 1 \text { head } \\
\text { of cattle per } 1 \text { ha }\end{array}$ & 454 & 850 & 4.84 & 13.18 & 18.02 \\
\hline $\begin{array}{c}\text { Grain-beet-dairy, } \\
0.3 \text { head of cattle } \\
\text { per } 1 \text { ha }\end{array}$ & 1361 & 250 & 14.51 & 3.88 & 18.39 \\
\hline $\begin{array}{c}\text { Farm. Grain } \\
\text { specialization }\end{array}$ & 1420 & - & 15.14 & - & 15.14 \\
\hline \multicolumn{6}{|c|}{ Transition Zone } \\
\hline $\begin{array}{l}\text { Grain-beet-dairy. } 1 \\
\text { head of cattle per } 1 \\
\text { ha, perennial herb } \\
\text { up to } 30 \% \text { of } \\
\text { arable land }\end{array}$ & 678 & 1000 & 7.23 & 15.51 & 22.74 \\
\hline
\end{tabular}

\begin{tabular}{|c|c|c|c|c|c|}
\hline \multirow[b]{2}{*}{$\begin{array}{c}\text { Features of } \\
\text { options }\end{array}$} & \multicolumn{2}{|c|}{$\begin{array}{c}\text { Humus } \\
\text { formed, } \\
\mathrm{kg} / \mathrm{ha}\end{array}$} & \multicolumn{2}{|c|}{$\begin{array}{l}{ }^{*} \text { Cost of } \\
\text { humus, } \\
\text { USD/ha }\end{array}$} & \multirow{2}{*}{ 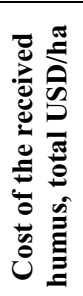 } \\
\hline & 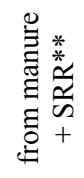 & 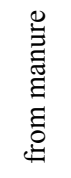 & 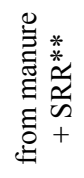 & 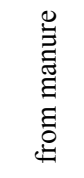 & \\
\hline \multicolumn{6}{|c|}{ Polissia Zone } \\
\hline $\begin{array}{l}\text { Grain-meat- dairy } \\
1.5-2 \text { heads of } \\
\text { cattle per } 1 \text { ha, } \\
\text { perennial herb up } \\
\text { to } 30 \% \text { of arable } \\
\text { land }\end{array}$ & 737 & 1200 & 7.85 & 18.61 & 26.46 \\
\hline
\end{tabular}

* Average calculated price of one centner of humus from manure is $1.55 \mathrm{USD}$; $1 \mathrm{c}$ humus from straw and stubble remains -3.0 USD

${ }^{* *} \mathrm{SRR}-$ stubble-root remains

Source: Authors' presentation

The data of Table 3 enable to determine the proportion of newly formed humus, which can be obtained as a result of the use of plant organic fertilizers, and to define the amount of humus to be supplemented by other sources of organic matter, e.g. manure. This allows for the estimated valuation of the humus balance per 1 ha of arable land, depending on the specialization and agro-climatic zones under the conditions of Sumy region (Ukraine). The figures are as follows: in the Forest-Steppe Zone the mineralized humus may be replenished by $68.7 \%$ at the expense of any alternative means of vegetable origin; in the Transitional Zone - by $40.4 \%$; in Polissia Zone - by $38 \%$.

Manure can be used to restore the shortage of organic substances, but an increase of its share in the total mass of organic fertilizers leads to the increase in expenditure on the humus formation on 1 ha from $15.14 \mathrm{USD} / \mathrm{ha}$ in the Forest-Steppe Zone to $26.46 \mathrm{USD} / \mathrm{ha}$ in Polissia Zone.

Natural fertility is the fertility, by means of which it is possible to get a certain harvest, without any additional measures of the fertility increase, subject to the requirements of the technologies. Under favorable agro-climatic conditions, the natural capacity of grain crops grown in Sumy region (Ukraine) in the ForestSteppe Zone is $26.4 \mathrm{c} / \mathrm{ha}, 19.5 \mathrm{c} / \mathrm{ha}$ in the Transition Zone, in Polissia Zone - $13.6 \mathrm{c} /$ ha [15]. The calculation of the economic efficiency of applying the agricultural technologies of deficit-free humus balance shows that the greatest efficiency is observed in the Forest-Steppe Zone compared to the Transitional Zone and Polissia Zone (Table 4). At the same time, the cost of additionally produced products is greater on the less fertile soils of Polissia and Transitional Zones than in the Forest-Steppe Zone. 
Table 4. The estimated economic evaluation of the agricultural technologies of deficit-free humus balance per 1 ha when growing winter wheat in Sumy region (Ukraine) ${ }^{*}$.

\begin{tabular}{|c|c|c|c|c|c|}
\hline \multirow[b]{3}{*}{$\begin{array}{l}\text { Agro- } \\
\text { climatic } \\
\text { zones }\end{array}$} & \multirow{3}{*}{ 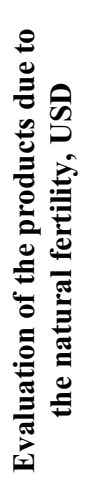 } & \multicolumn{4}{|c|}{$\begin{array}{l}\text { Economic indicators of } \\
\text { agricultural technologies of } \\
\text { deficit-free humus balance }\end{array}$} \\
\hline & & \multicolumn{3}{|c|}{ Valuation, USD } & \multirow[b]{2}{*}{ 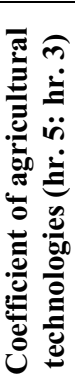 } \\
\hline & & 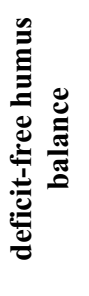 & 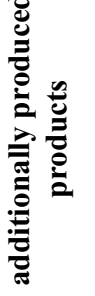 & 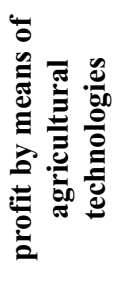 & \\
\hline 1 & 2 & 3 & 4 & 5 & 6 \\
\hline Polissia & 73.39 & 18.93 & 81.11 & 62.18 & 3.28 \\
\hline Transitional & 79.95 & 16.61 & 75.71 & 59.10 & 3.56 \\
\hline $\begin{array}{l}\text { Forest- } \\
\text { Steppe }\end{array}$ & 142.91 & 13.91 & 70.30 & 56.39 & 4.05 \\
\hline
\end{tabular}

* Calculated by the author according to the data of the Office for National Statistics of Ukraine [2]

It should be noted that keeping a deficit-free humus balance creates favorable conditions to obtain stable yields, enables to increase yields not only in the year of organic matter application to the soil, but in subsequent years, that is the goal of the effective and qualitative organizational-economic mechanism of fertility management for the proper provision of society with foodstuff.

The effectiveness of the soil fertility management largely depends on the applied methods and capabilities of agricultural enterprises and farms on providing them with the means of the fertility increase, the level of the adequate management of these processes, the attraction of investments to grow ecologically clean farm products.

\section{Conclusions}

The challenging ecological situation in the Ukrainian agriculture is characterized by the lack of targeted financial resources required for the reproduction of natural resources. The environmental and economic problems in the agrarian sector are the result of the overloading of the extensive development of agriculture in the past, the lack of effective policy of its ecologization. The most effective solution to the problems of ecological development of agricultural production should become the intensive investment activities aimed at financing the acquisition of environmental and resource-saving technologies, the implementation of other measures for the conservation of natural resources in the agrarian sector.

The environmental and economic investing is aimed at increasing economic efficiency of agricultural production with the consideration of environmental interests that enables agricultural production to get to a whole new level, to develop agro-ecological farming. The essence of this transition is the quantitative accumulation of qualitative changes in the elements of the agricultural production ecologization system, the new structural combination of which in their interrelation and interaction will lead to the more effective way of the natural resource management in this industry. The development of the investment management in agro-ecological farming will enable to expand the production of environmentally friendly farm products, to improve the fertility of agricultural land, to find internal investment resources for farms in order to reduce the cost of agricultural products.

\section{References}

1. O. Sobkevych, V. Rusan, A. Yurchenko et al., Development of agricultural production as a prerequisite for food security in Ukraine, NISS, 39 (2017)

2. [online] [access: date] State Statistics Service of Ukraine: http://www.ukrstat.gov.ua/

3. O. Dudchyk, Global and national problems of economics, 4, 826-829 (2015)

4. S. Pyrozhkov, M. Khvesyk, Economic evaluation of the Ukrainian natural wealth, Public Institution "Institute of Environmental Economics and Sustainable Development of the National Academy of Sciences of Ukraine”, 396 (2015)

5. Yu. Lupenko, M. Kisil, Strategic directions of the investment provision of the Ukrainian agricultural development till 2020, NSC IAE, 66 (2012)

6. A. Sahrbacher, J. Hristov, M. Brady, A combined approach to assess the impacts of Ecological Focus Areas on regional structural development and agricultural land use, Review of Agricultural, Food and Environmental Studies, 98 (3), 111-144 (2017)

7. A. Standar, J. Średzińska, Wykorzystanie analizy czynnikowej do badania determinant dochodów gospodarstw rolnych (na przykładzie krajów Europy Srodkowo-Wschodniej), Zeszyty Naukowe SGGW Ekonomika i Organizacja Gospodarki Żywnościowej, 118 (4), 5-17 (2017)

8. J. Tomaszewski, Fundusze inwestycji odpowiedzialnych społecznie w Europie - struktura $i$ trendy rozwojowe, Zarządzanie finansami i rachunkowość, 4 (2), 17-26 (2016)

9. Yu. Lupenko, Development of agrarian sector of the Ukrainian economy: forecasts and prospects, Scientific Bulletin of Mukachevo State University, Series "Economics", 2 (4), Part 2, 30-34 (2015)

10. V. Kutsenko, Ya. Ostafiichuk, M. Ilyina et al., Socio-ecological priorities for sustainable rural development, Public Institution "Institute of Environmental Economics and Sustainable Development of the National Academy of Sciences of Ukraine", 351 (2016)

11. Yu. Aviati, R. Karsidi, D. Tri Kartono, S. Anantanyu, The Development of Corn Farmers' 
Entrepreneurial Competencies in Indonesia, International Journal of Ecology \& Development, 31 (4), 78-83 (2016)

12. St. Brosig, T. Glauben, I. Levkovych, S. Prehn, R. Teuber, Are We Moving Towards Functioning Agricultural Markets and Trade Relations? Journal of Agricultural Economics, 67 (3), 677-684 (2016)

13. P. Sabluk, M. Kodenska, Conceptual framework for the development and implementation of investment programs in agri-industrial production, NSC IAE, 46 (2012)

14. S. Sharybar, Actual Problems of Economics, 10 (160), 270-275 (2014)

15. Yu. Lupenko, V. Mesel-Veseliak, Strategic directions of the Ukrainian agricultural development till 2020, NSC IAE, 218 (2012) 